\title{
Annual dry matter, metabolisable energy and nitrogen yields of six dryland pastures six and seven years after establishment
}

\author{
A. MILLS and D.J. MOOT \\ Agriculture and Life Sciences Division, Lincoln University, Lincoln 7647, Lincoln \\ millsa@lincoln.ac.nz
}

\begin{abstract}
Dry matter (DM) yields, botanical composition, liveweight production and pasture quality of six grazed dryland pastures established in 2002 at Lincoln University, Canterbury, are reported for Years 6 (2007/08) and 7 (2008/09). Lucerne (Medicago sativa) yielded $14.0 \mathrm{t} \mathrm{DM} / \mathrm{ha} / \mathrm{yr}$ and sheep liveweight (LW) production totalled $903(2007 / 08)$ and $1141 \mathrm{~kg} / \mathrm{ha} / \mathrm{yr}$ (2008/09). Metabolisable energy (ME) on offer ( 134 $\mathrm{GJ} / \mathrm{ha} / \mathrm{yr}$ ) and $\mathrm{N}$ yield (>500 $\mathrm{kg} / \mathrm{ha} / \mathrm{yr})$ from the lucerne exceeded those of grass-based pastures. Yields (9.811.2 t DM/ha/yr) and liveweight production (814-912 $\mathrm{kg} / \mathrm{ha} / \mathrm{yr}$ ) from cocksfoot (Dactylis glomerata) pastures established with subterranean (Trifolium subterraneum) clover were greater than all other grass-based pastures. Annual ME was 79-96 GJ/ha and N yield was 269$316 \mathrm{~kg} / \mathrm{ha}$ from the cocksfoot, subterranean clover and volunteer white clover (T. repens) components. For Year 7, the contribution of unsown weeds and grasses in cocksfoot-based pastures was $\sim 28 \%$ of total annual yield compared with $55 \%$ in ryegrass (Lolium perenne)/ white clover pastures. Consequently, the ME and $\mathrm{N}$ yields from sown pasture components in ryegrass/white
\end{abstract}

clover pastures were lower than those from cocksfootbased pastures. These results indicate dryland farms with lucerne and/or cocksfoot/sub clover pastures can produce higher DM yields from more persistent pasture species. Persistence led to more ME and $\mathrm{N}$ on offer to grazing livestock, which resulted in higher liveweight production than from the ryegrass pastures.

Keywords: balansa clover, Caucasian clover, growth rates, pasture quality, T. ambiguum, T. michelianum

\section{Introduction}

To maintain the profitability of dryland farming systems exposed to periodic moisture stress it is important to use available resources efficiently within a narrow, but generally reliable, production window in spring. At this time temperatures are increasing and stored soil moisture is usually non-limiting to growth. Maximising dry matter (DM) and liveweight production allows priority stock to be sold in prime condition from the property by early summer. This can reduce the risk associated with maintaining production in summer/autumn when rainfall is more variable and unpredictable. To ensure long-term sustainability several criteria must be met 1)

Figure 1 Monthly (a) rainfall $(\mathrm{mm})$ and $(\mathrm{b})$ mean air temperature $\left({ }^{\circ} \mathrm{C}\right)$ at Lincoln, Canterbury. Total annual rainfall was $651 \mathrm{~mm}$ in $2007 / 08$, $767 \mathrm{~mm}$ in 2008/09. Long-term means (LTM) are for the period 1975-2001. Data are from the Broadfields meteorological site located $2 \mathrm{~km}$ north of the experiment site.
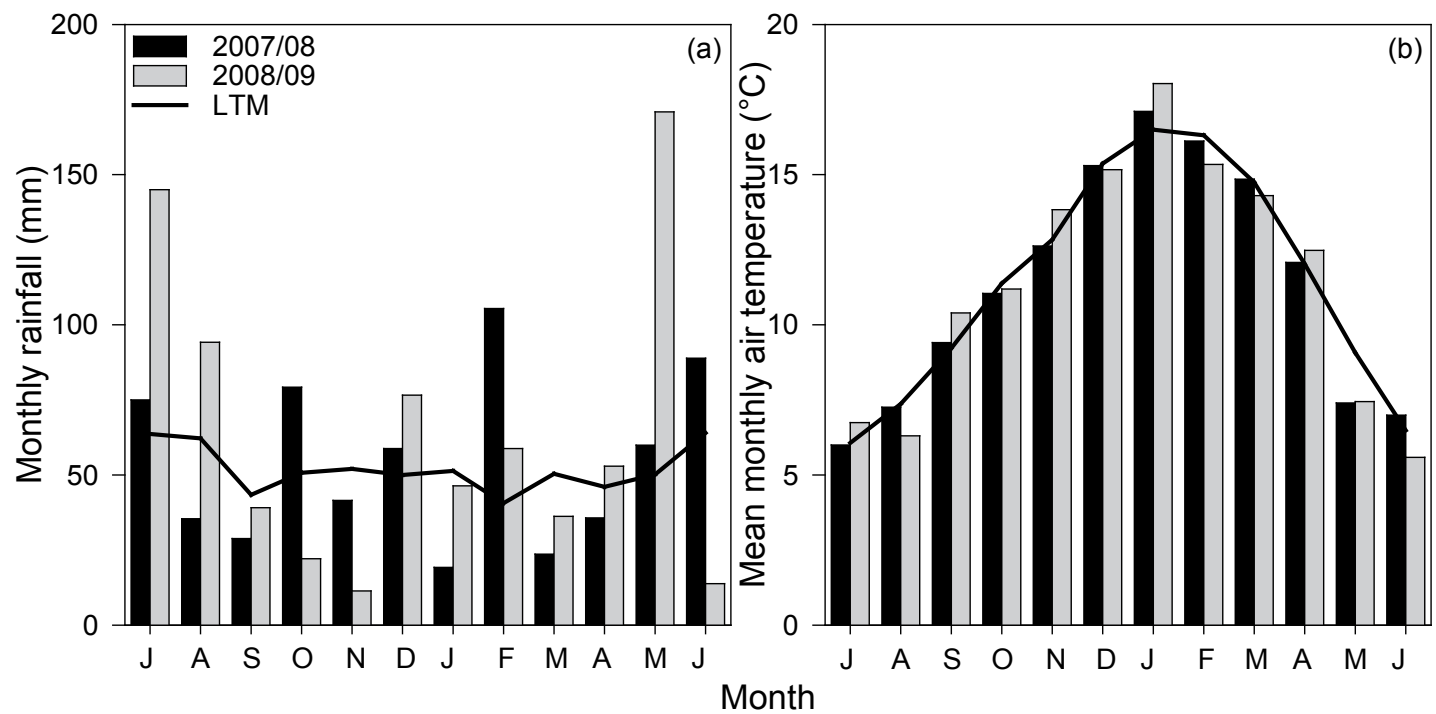
the quantity and quality of spring feed should meet stock demand during lambing/lactation 2) pastures must be able to efficiently use the "free" water resource stored in the soil and 3) pasture species must be able to survive, recover and persist through periods of water stress to reduce costs associated with frequent pasture renewal.

In Years 1-5 of the 'MaxClover' dryland grazing experiment total annual yields from lucerne monocultures $(10.0-18.5 \mathrm{t} \mathrm{DM} / \mathrm{ha} / \mathrm{yr})$ and sheep liveweight production (833-1 $100 \mathrm{~kg} \mathrm{LW} / \mathrm{ha} / \mathrm{yr}$ ) were superior to grass-based pastures (Mills et al. 2008a; $2008 \mathrm{~b}$ ) in most years. However, winter production of lucerne was low and it must be rotationally grazed so high quality grass-based pastures are needed to complement its use particularly during lambing. Cocksfoot/subterranean clover pastures have previously been the most productive of the grassbased pastures. To quantify productivity differences, and allow comparison with other experiments, the DM yield, botanical composition, annual metabolisable energy (ME), nitrogen (N) yield and liveweight production from Years $6(2007 / 08)$ and 7 (2008/09) of the 'MaxClover' grazing experiment are presented.

\section{Materials and Methods}

Full experimental details have been reported previously (Brown et al. 2006; Mills et al. 2008a). Briefly, four replicates of six dryland pastures were established on a variable depth Templeton silt loam soil at Lincoln University in autumn 2002. Pastures were 'Vision' cocksfoot (CF) established with 'Denmark' subterranean $(\mathrm{CF} / \mathrm{Sub})$, 'Bolta' balansa (T. michelianum (CF/Bal), 'Demand' white $(\mathrm{CF} / \mathrm{Wc})$ or 'Endura' caucasian (T. ambiguum; $\mathrm{CF} / \mathrm{Cc}$ ) clovers, an 'Aries HD'

Table 1

Harvest dates and regrowth duration (d) in 2007/08 and 2008/09 for the 'MaxClover' grazing experiment at Lincoln University, Canterbury, New Zealand. Harvest dates reported for lucerne monocultures, which were harvested before grazing, are the average harvest date of the six plots.

\begin{tabular}{lccccccc}
\hline \multicolumn{3}{c}{ 2007/08 (Year 6) } & \multicolumn{5}{c}{ 2008/09 (Year 7) } \\
\hline \multicolumn{2}{l}{ Grass pastures } & \multicolumn{2}{c}{ Lucerne } & Grass pastures & \multicolumn{2}{c}{ Lucerne } \\
Date & (d) & Date & (d) & Date & (d) & Date & (d) \\
\hline $28 / 08$ & 62 & $5 / 10$ & 107 & $3 / 09$ & 68 & $23 / 09$ & 84 \\
$27 / 09$ & 30 & $20 / 11$ & 46 & $8 / 10$ & 35 & $31 / 10$ & 38 \\
$29 / 10$ & 32 & $25 / 12$ & 35 & $10 / 11$ & 33 & $4 / 12$ & 34 \\
$27 / 11$ & 29 & $28 / 01$ & 34 & $5 / 01$ & 56 & $12 / 01$ & 39 \\
$7 / 01$ & 41 & $21 / 03$ & 53 & $2 / 03$ & 56 & $16 / 03$ & 63 \\
$6 / 03$ & 59 & $18 / 05$ & 58 & $6 / 04$ & 35 & $27 / 05$ & 72 \\
$15 / 04$ & 40 & $30 / 06$ & 43 & $30 / 06$ & 85 & $30 / 06$ & 34 \\
$26 / 06$ & 72 & & & & & & \\
\hline Annual & 365 & \multicolumn{7}{c}{376} & 368 & & 364 \\
\hline
\end{tabular}

AR1 perennial ryegrass/white clover $(\mathrm{RG} / \mathrm{Wc})$ control and a 'Kaituna' lucerne (Luc) monoculture. Plots (0.05 ha) were individually fenced and gateways opened onto central laneways to facilitate movement of livestock. In 2003 an additional two replicates were established on an adjacent site. Thus, from the beginning of the third growth season, measurements were from six pasture treatments replicated six times.

\section{Environmental conditions}

Long-term mean (LTM) annual (Jul-Jun) rainfall is 624 $\mathrm{mm} / \mathrm{yr}(1975-2001)$ and ranges from 41-64 mm/month throughout the year. Annual rainfall was $651 \mathrm{~mm}$ in 2007/08 and $767 \mathrm{~mm}$ in 2008/09 (Fig. 1a). In both $2007 / 08$ and 2008/09 mean monthly air temperatures were above the average LTM in January.

\section{Measurements}

For the grass-based pastures there were eight rotations in 2007/08 and seven in 2008/09 (Table 1). At the start of each regrowth period an area was pre-trimmed to 25 $\mathrm{mm}$ and an exclosure cage placed to exclude grazing sheep. At the end of each 29-85 d regrowth period one $0.2 \mathrm{~m}^{2}$ quadrat was cut to a residual height of $\sim 25$ $\mathrm{mm}$. All grass pastures were harvested on the same day. Lucerne monocultures had seven rotations annually (33-107 days) and yield was measured from five $0.2 \mathrm{~m}^{2}$ quadrats per plot. Each lucerne plot was harvested before sheep were moved to a new plot and the mean start date of harvests in the six lucerne plots is reported for simplicity.

Grazing commenced in the first lucerne paddock 24 days later than grass-based pastures in 2007/08 and 17 days later in 2008/09. Subsamples were taken to determine botanical composition (Cayley \& Bird 1996). These were sorted into sown grass, sown legume, volunteer white clover (VWC), unsown species and dead fractions. Samples were dried at $65{ }^{\circ} \mathrm{C}$ until a constant weight. Sown grass and legume subsamples were retained and ground. Pasture quality on sown pasture components was determined by near infrared spectroscopy (NIRS) at the Analytical Laboratory Unit (Lincoln University). Annual metabolisable energy and $\mathrm{N}$ yields of sown pasture components were then calculated. For annual $\mathrm{N}$ yields the mean $\mathrm{N} \%$ of white clover from the $\mathrm{CF} / \mathrm{Wc}$ and $\mathrm{RG} / \mathrm{Wc}$ pastures was applied to volunteer white clover recorded in Sub, Bal and $\mathrm{Cc}$ based pastures.

Annual liveweight production for Year $6(2007 / 08)$ and Year $7(2008 / 09)$ was determined as reported previously (Brown et al. 2006). To account for variations between animal demand and pasture supply, pastures were grazed with Coopworth hoggets which were replaced with weaned ewe lambs in late spring/ summer, using a 'put and take' system. Between 5 and 
Table 2 Total grazing days/ha (Total) and "production" (P) grazing days/ha. The difference is grazing days by maintenance stock, where liveweight gain was assumed to be zero.

\begin{tabular}{lcccc}
\hline & \multicolumn{2}{c}{$2007 / 08$} & \multicolumn{2}{c}{$2008 / 09$} \\
Pasture & Total & $(\mathrm{P})$ & Total & $(\mathrm{P})$ \\
CF/Sub & 1812 & 1647 & 1807 & 1728 \\
CF/Bal & 1720 & 1557 & 1574 & 1495 \\
CF/Wc & 1815 & 1602 & 1557 & 1466 \\
CF/Cc & 1881 & 1674 & 1666 & 1573 \\
RG/Wc & 1590 & 1385 & 1418 & 1385 \\
Luc & 1448 & 1448 & 1614 & 1555 \\
\hline
\end{tabular}

10 "core" animals were selected and assigned to one of the six pasture treatment groups. These animals were weighed "empty" before and after "production" grazing periods (Table 2). During "production" grazing periods treatment groups rotationally grazed the six replicates of their assigned pasture treatment. "Production" periods ended when there was insufficient growth to maintain grazing by "core" groups. Lucerne was rotationally grazed throughout active growth whereas grass-based pastures underwent simulated set stocking in early spring. For pasture established with annual clovers stock were removed in late spring to allow for reseeding. Pastures were de-stocked over winter (Jun-Aug) except for ewes that were used to "clean-up" all pastures.

\section{Analysis}

Data were analysed by one way ANOVA in Genstat
11 and, when significant, means were separated by Fisher's protected least significant difference (LSD) at the $\alpha=0.05$ level. Data for DM production by lucerne stands were included in the analysis of annual production ( 35 d.f.) but, due to differences in the time of harvests, were excluded from analysis of individual harvest dates ( 29 d.f).

\section{Results}

DM production and growth rates

Lucerne yield was $14.0 \mathrm{t} \mathrm{DM} / \mathrm{ha}$ in both years and exceeded $(\mathrm{P}<0.001)$ all grass-based pastures (Fig. 2). Yield of the $\mathrm{CF} / \mathrm{Sub}$ pastures was $11.2 \mathrm{t} \mathrm{DM} / \mathrm{ha}$ in $2007 / 08$ and $9.8 \mathrm{t} \mathrm{DM} / \mathrm{ha}$ in 2008/09. This was at least $24 \%$ more $(\mathrm{P}<0.001)$ DM than all other grass-based pastures in Year 6 and at least $40 \%$ more in Year 7 (2008/09). Over the two growth seasons mean daily growth rates ranged from $7 \pm 2.1 \mathrm{~kg} \mathrm{DM} / \mathrm{ha} / \mathrm{d}$ for grassbased pastures in winter (26/6/2008) to $92 \mathrm{~kg} \mathrm{DM} / \mathrm{ha} / \mathrm{d}$ $(25 / 12 / 2007)$ from lucerne (Fig. 3). Excluding lucerne, the mean daily growth rate of the $\mathrm{CF} / \mathrm{Sub}$ pastures was greater than $(\mathrm{P}<0.01)$ other grass-based pastures in 7 of the 15 regrowth periods. In six rotations growth rates of the grass-based pastures were unaffected by treatment.

\section{Botanical composition}

By definition lucerne monocultures had the highest legume content ( $13.1 \mathrm{t} \mathrm{DM} / \mathrm{ha} / \mathrm{yr}$; Fig. 4$)$. Of the grassbased pastures, sown species (grass + clover) in the $\mathrm{CF} /$ Sub pastures yielded $8.2 \mathrm{t} / \mathrm{ha}$ in Year 6 and $6.8 \mathrm{t} \mathrm{DM} / \mathrm{ha} /$ $\mathrm{yr}$ in Year 7. These were greater $(\mathrm{P}<0.001)$ than sown

Figure 2 Total accumulated annual dry matter (DM) yield of six dryland pastures in 2007/08 (Year 6) and 2008/09 (Year 7) at Lincoln University, Canterbury. Error bars are SEM for total annual DM yield.

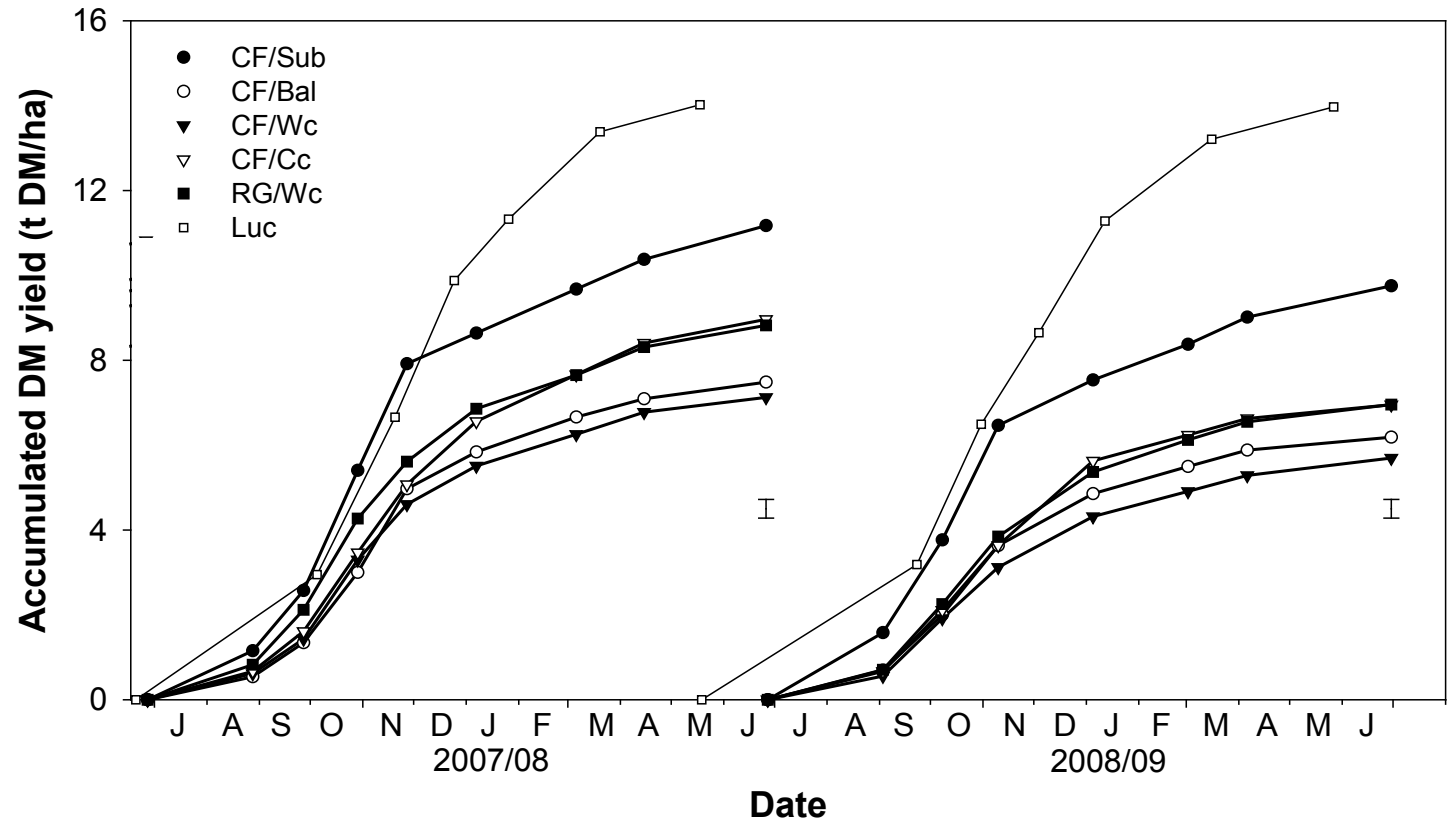


Figure 3 Mean daily growth rate (kg DM/ha/d) of dryland CF/Sub, CF/Bal, CF/Wc, CF/Cc, RG/Wc and lucerne pastures for 2007/08 (Year 6) and 2008/09 (Year 7) at Lincoln University, Canterbury. Lucerne was excluded from the analysis but is shown for reference. Error bars are SEM for rotations where treatment differences occurred.

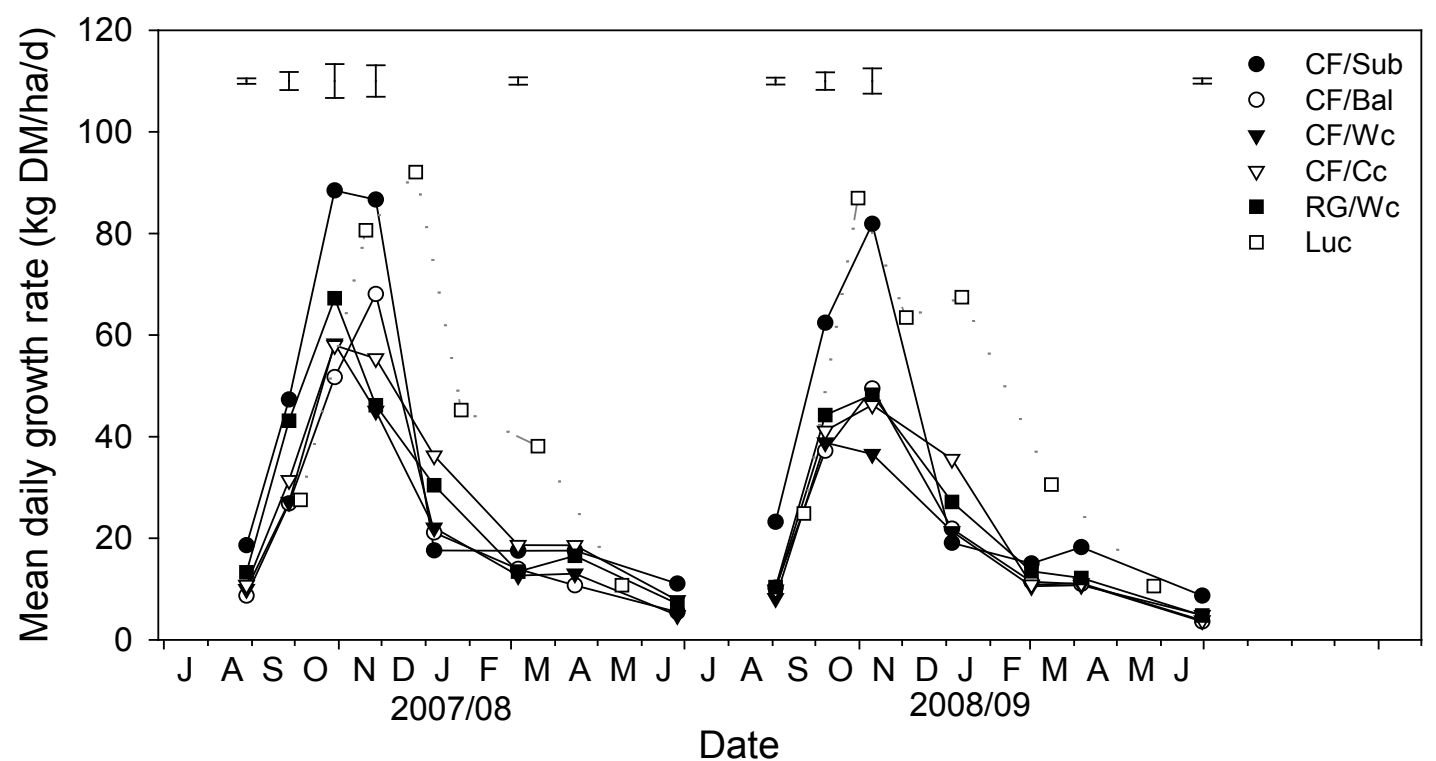

Figure 4 Annual contributions of sown grass, sown legume, unsown pasture components (volunteer white clover + dicot weed + unsown weed grasses) and dead material to total annual yield in 2007/08 (a) and 2008/09 (b). Error bars are SEM for total sown species (sown grass + sown legume).

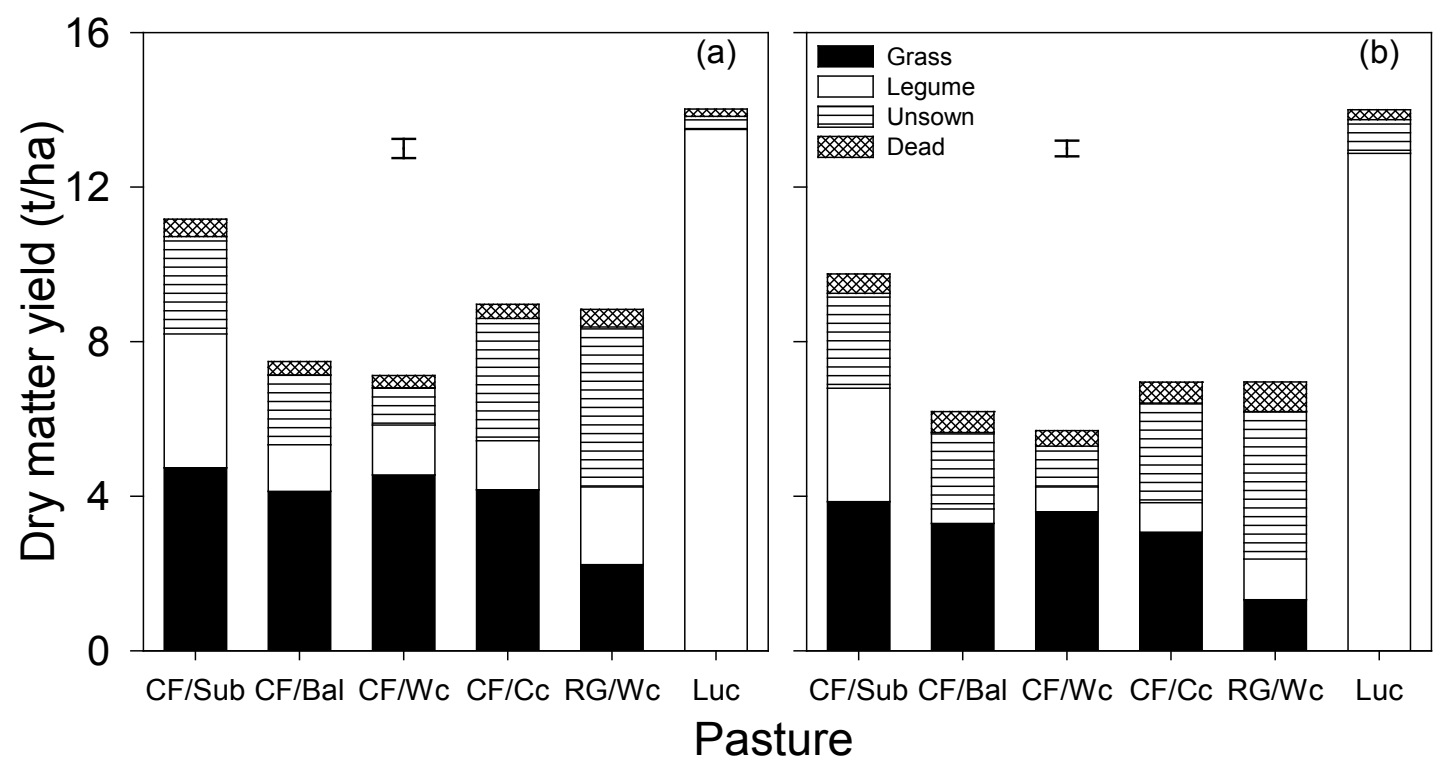

species yields in all other pastures which were lowest at $2.4 \mathrm{t} \mathrm{DM} / \mathrm{ha} / \mathrm{yr}$ in RG/Wc pastures in Year 7. Sub clover yielded 3.5 and $2.9 \mathrm{t} \mathrm{DM} / \mathrm{ha} / \mathrm{yr}$ which was superior $(\mathrm{P}<0.001)$ to all other sown clovers in both years. In $2007 / 08$, volunteer white clover contributed 1.3 t DM/ ha/yr to the $\mathrm{CF} / \mathrm{Cc}$ pastures compared $(\mathrm{P}<0.01)$ with
$0.5 \pm 0.17 \mathrm{t} \mathrm{DM} / \mathrm{ha}$ in $\mathrm{CF} / \mathrm{Sub}$ and $\mathrm{CF} / \mathrm{Bal}$ pastures. In $2008 / 09$, volunteer white clover was similar in the three treatments $(0.5 \pm 0.16 \mathrm{t} / \mathrm{ha} / \mathrm{yr})$.

\section{Annual liveweight production}

In Years 6 and 7 liveweight production from sheep 
Figure $5 \quad$ Nitrogen yield (kg N/ha/yr) of the sown grass, sown legume and volunteer white clover (VWC) components of six dryland pastures at Lincoln University, Canterbury in 2007/08 (Year 6) and 2008/09 (Year 7). Error bars are SEM.
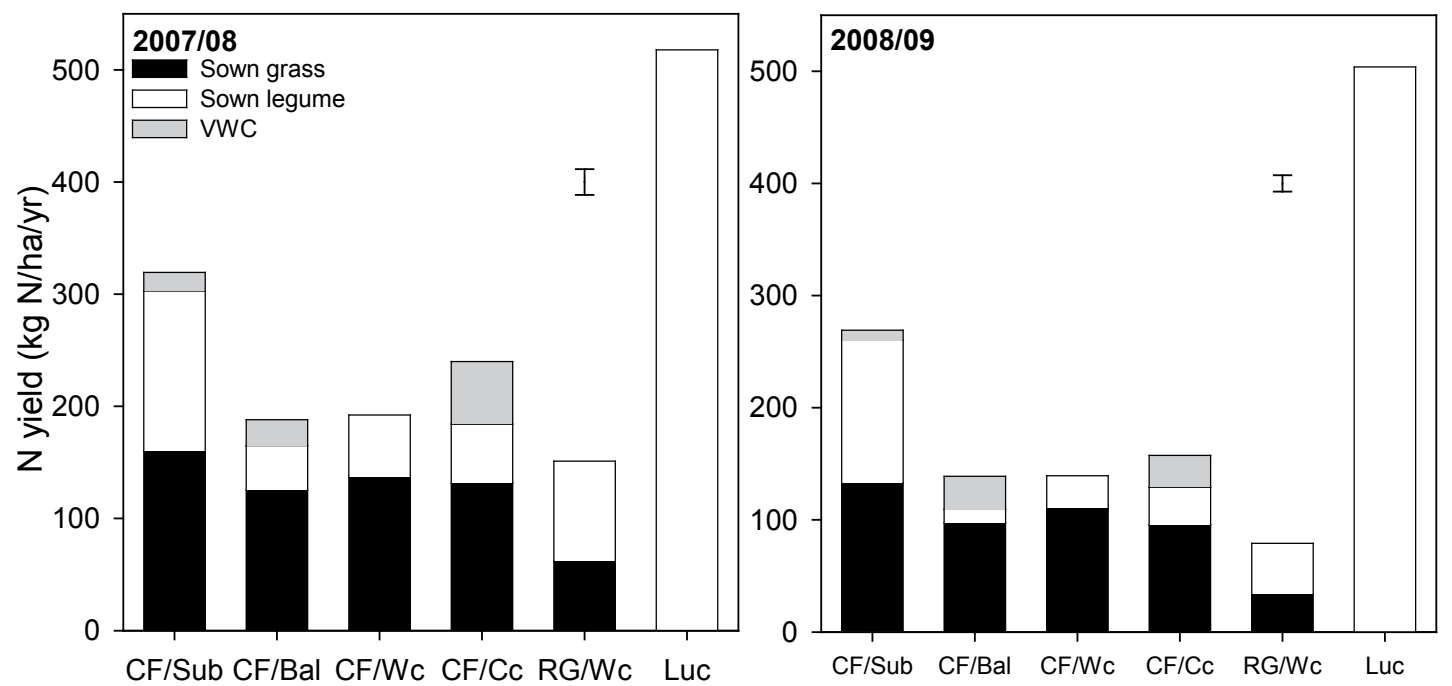

Pasture type

Table 3 Annual sheep liveweight production $(\mathrm{kg} / \mathrm{ha})$ from six dryland pastures in Year $6(2007 / 08)$ and Year 7 (2008/09) at Lincoln University, Canterbury.

\begin{tabular}{lcc}
\hline Pasture & $2007 / 08$ & $2008 / 09$ \\
\hline CF/Sub & $814_{\mathrm{b}}$ & $912_{\mathrm{b}}$ \\
$\mathrm{CF} /$ Bal & $543_{\mathrm{de}}$ & $702_{\mathrm{c}}$ \\
$\mathrm{CF} / \mathrm{Wc}$ & $503_{\mathrm{e}}$ & $675_{\mathrm{c}}$ \\
$\mathrm{CF} / \mathrm{Cc}$ & $655_{\mathrm{c}}$ & $719_{\mathrm{c}}$ \\
$\mathrm{RG} / \mathrm{Wc}$ & $613_{\mathrm{cd}}$ & $711_{\mathrm{c}}$ \\
Luc & $903_{\mathrm{a}}$ & $1067_{\mathrm{a}}$ \\
\hline SEM & $33.2^{*}$ & 52.0 \\
\hline P value & ${ }_{\star \star *}$ &
\end{tabular}

Significance level ${ }^{\star \star \star}=0.001$

rotationally grazing lucerne was superior $(\mathrm{P}<0.001)$ to all other pastures (Table 3). In both years the CF/Sub pastures produced at least $24 \%$ more $(\mathrm{P}<0.001)$ LW than all other grass-based pastures.

\section{Metabolisable energy content and ME yield}

The average ME content of ryegrass was $\sim 11.7 \mathrm{MJ} / \mathrm{kg} \mathrm{DM}$ compared with $\sim 11.2 \mathrm{MJ} / \mathrm{kg}$ DM for cocksfoot $(\mathrm{P}<0.001)$ (Table 4). Across individual harvests sown grass $\mathrm{ME}$ ranged from 9.8-12.4 $\mathrm{MJ} / \mathrm{kg} \mathrm{DM}$ (data not shown). Lucerne ME averaged $\sim 11.0 \mathrm{MJ} / \mathrm{kg} \mathrm{DM}$ which was lower than the clovers. The ME yield (GJ/ha/yr) of ryegrass was less than half $(\mathrm{P}<0.01)$ that on offer from cocksfoot in both years (Table 5). As expected, the ME yield of lucerne was greatest ( 133.8 GJ/ha/yr), and that from Sub clover ( $\sim 36.8 \mathrm{GJ} \mathrm{ME} / \mathrm{ha} / \mathrm{yr})$ was almost double that of white
Table 4 Annual average ME (MJ/kg DM) of the sown pasture components of six dryland pastures in Year 6 (2007/08) and Year 7 (2008/09) at Lincoln University, Canterbury.

\begin{tabular}{lllll}
\hline & \multicolumn{2}{c}{$2007 / 08$} & \multicolumn{2}{c}{$2008 / 09$} \\
Pasture & Grass & Legume & Grass & Legume \\
\hline CF/Sub & $11.3_{\mathrm{b}}$ & $11.2_{\mathrm{b}}$ & $11.1_{\mathrm{b}}$ & $11.4_{\mathrm{c}}$ \\
CF/Bal & $11.3_{\mathrm{b}}$ & $11.4_{\mathrm{b}}$ & $11.1_{\mathrm{b}}$ & $12.0_{\mathrm{a}}$ \\
CF/Wc & $11.3_{\mathrm{b}}$ & $11.8_{\mathrm{a}}$ & $11.2_{\mathrm{b}}$ & $12.0_{\mathrm{a}}$ \\
CF/Cc & $11.3_{\mathrm{b}}$ & $11.3_{\mathrm{b}}$ & $11.2_{\mathrm{b}}$ & $11.8_{\mathrm{b}}$ \\
RG/Wc & $11.6_{\mathrm{a}}$ & $12.0_{\mathrm{a}}$ & $11.8_{\mathrm{a}}$ & $11.8_{\mathrm{b}}$ \\
Luc & - & $10.9_{\mathrm{c}}$ & - & $11.0_{\mathrm{d}}$ \\
\hline SEM & 0.04 & 0.10 & 0.04 & 0.05 \\
P value & $\star \star \star$ & $\star \star \star$ & $* \star *$ & \\
\hline
\end{tabular}

Note: ${ }^{\star \star \star}=P<0.001$

clover in RG/Wc pastures ( $18.0 \mathrm{GJ} / \mathrm{ha} / \mathrm{yr})$.

\section{Nitrogen concentration and $\mathrm{N}$ yield}

The $\mathrm{N}$ concentration of grasses ranged from 1.9-4.6\% at individual harvests (data not shown). The annual average $\mathrm{N} \%$ of ryegrass $(2.7 \%)$ was less $(\mathrm{P}<0.001)$ than cocksfoot $(3.0-3.5 \% \mathrm{~N})$ in both years (Table 6). The $\mathrm{N}$ concentration of the cocksfoot with Sub (3.5\%) was greater than from all other cocksfoot-based pastures in both years. Lucerne yielded $510 \mathrm{~kg} \mathrm{~N} / \mathrm{ha} / \mathrm{yr}$ (Fig. 5) which was superior $(\mathrm{P}<0.001)$ to all grass-based pastures. The sown species in the RG/Wc pastures yielded only $151 \mathrm{~kg} \mathrm{~N} / \mathrm{ha}$ in Year 6 and $79 \mathrm{~kg} \mathrm{~N} / \mathrm{ha}$ in Year 7. 
Table 5 Accumulated annual metabolisable energy (ME) yield (GJ/ha) of sown grass, sown legume and volunteer white clover (VWC) in six dryland pastures at Lincoln University in 2007/08 (Year 6) and 2008/09 (Year 7).

\begin{tabular}{|c|c|c|c|c|c|c|c|c|}
\hline \multirow[b]{2}{*}{ Pasture } & \multicolumn{4}{|c|}{$2007 / 08$} & \multicolumn{4}{|c|}{$2008 / 09$} \\
\hline & Grass & Legume & VWC & Total & Grass & Legume & VWC & Total \\
\hline CF/Sub & $51.3_{a}$ & $39.8_{b}$ & $4.7_{b}$ & $95.9_{b}$ & $43.0_{a}$ & $33.8_{b}$ & 2.5 & $79.2_{b}$ \\
\hline $\mathrm{CF} / \mathrm{Bal}$ & $45.5_{a}$ & $14.0_{\mathrm{c}}$ & $6.4_{b}$ & $65.8_{\mathrm{cd}}$ & $36.5_{a}$ & $4.0_{c}$ & 8.1 & $48.6_{c}$ \\
\hline $\mathrm{CF} / \mathrm{Wc}$ & $50.5_{a}$ & $15.4_{c}$ & - & $65.9_{c d}$ & $38.8 a$ & $7.8_{c}$ & - & $46.4_{c}$ \\
\hline $\mathrm{CF} / \mathrm{Cc}$ & 46.8 a & $14.6_{c}$ & $15.2 \mathrm{a}$ & $76.6_{\mathrm{bc}}$ & $33.9_{a}$ & $7.7_{\mathrm{c}}$ & 7.7 & 49.3 c \\
\hline $\mathrm{RG} / \mathrm{Wc}$ & $26.0_{b}$ & $23.9_{c}$ & - & $49.9_{d}$ & $15.0_{b}$ & $12.1_{\mathrm{c}}$ & - & $27.0_{d}$ \\
\hline Luc & - & $139.1_{a}$ & - & $139.1_{a}$ & - & $128.4_{a}$ & - & $128.4_{a}$ \\
\hline SEM & 4.22 & 4.50 & 2.01 & 6.79 & 4.35 & 3.78 & 2.62 & 5.63 \\
\hline Significance & $\star \star$ & $\star \star \star$ & $\star \star$ & 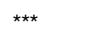 & ** & *** & NS & **夫 \\
\hline
\end{tabular}

Note: ${ }^{* *}=\mathrm{P}<0.01 ;{ }^{* *}=\mathrm{P}<0.001 ; \mathrm{NS}=$ non significant. Means followed by the same letter are similar at the $\mathrm{P}<0.05$ level of significance. Volunteer white clover ME yields were determined using the average of white clover ME determined from the CF/Wc and RG/Wc pastures as VWC samples were not retained for analysis.

Table 6 Annual average nitrogen content (\%) of the sown grass and sown legume components from six dryland pastures in Year 6 (2007/08) and Year 7 (2008/09) at Lincoln University, Canterbury.

\begin{tabular}{|c|c|c|c|c|}
\hline \multirow[b]{2}{*}{ Pasture } & \multicolumn{2}{|c|}{$2007 / 08$} & \multicolumn{2}{|c|}{ 2008/09 } \\
\hline & Grass & Legume & Grass & Legume \\
\hline CF/Sub & $3.4_{a}$ & $4.2_{b}$ & $3.5_{a}$ & $4.3_{b}$ \\
\hline CF/Bal & $3.1_{b}$ & $3.8 \mathrm{c}$ & $3.0_{c}$ & $4.1_{\mathrm{c}}$ \\
\hline $\mathrm{CF} / \mathrm{Wc}$ & $3.1_{b}$ & $4.2_{b}$ & $3.1_{b c}$ & $4.4_{\mathrm{a}}$ \\
\hline $\mathrm{CF} / \mathrm{Cc}$ & $3.2_{b}$ & $4.3_{b}$ & $3.2_{b}$ & $4.6_{a}$ \\
\hline $\mathrm{RG} / \mathrm{Wc}$ & 2.7 。 & $4.5_{\mathrm{a}}$ & $2.6_{d}$ & $4.3_{a b}$ \\
\hline Luc & - & $4.0_{c}$ & - & $3.8_{d}$ \\
\hline SEM & 0.05 & 0.08 & 0.05 & 0.09 \\
\hline$P$ value & $* \star \star$ & $\star \star \star *$ & $\star \star \star *$ & 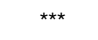 \\
\hline
\end{tabular}

Note: ${ }^{* \star \star}=\mathrm{P}<0.001$

\section{Discussion}

High animal production from productive and persistent high quality pastures is the basis for dryland pastoral farming in New Zealand. Lucerne continues to show superior DM yields (Fig. 2), quality (Table 5 \& Fig. 5) and sheep liveweight production (Table 3 ) in this experiment. This indicates that where lucerne can be grown it should be. Lucerne has been rotationally grazed to maintain long-term persistence, so it is recommended that lucerne stands are established on the deepest, well drained soils on flat to rolling land on a property that can be sub-divided. Exactly which environmental and soil conditions that will support lucerne production needs to be re-defined on-farm throughout the East Coast of New Zealand. Recent success in Marlborough (Avery et al. 2008) and Central Otago (Kearney et al. 2010, this volume) offer guidance for establishment and grazing management (Moot et al. 2003).

In contrast, the $\mathrm{CF} / \mathrm{Sub}$ pastures have consistently been the most productive (LW and DM) of the grass- based pastures (Mills et al. 2008a; 2008b). In Years 6 and 7, they yielded 2-3 times more metabolisable energy than the sown species in the ryegrass/white clover pastures (Table 5) despite a lower absolute ME (Table 4). Pasture management that maintained the annual clover in these cocksfoot pastures (Fig. 4) led to superior N\% and total $\mathrm{N}$ yield (Fig. 5) and has maintained high sheep liveweight gains (Table 3) over 7 years (Mills et al. 2008b). The success of this combination with subterranean clover, particularly in early spring (Brown et al. 2006) supports its use commercially (Costello \& Costello 2003) and recommendations to overdrill Sub clover into existing grass-dominant pastures (Ates et al. 2010, this volume) to extend their productive life. These results suggest that in dryland environments, where perennial ryegrass and white clover have failed to persist, lucerne should be considered as the first pasture option followed by mixtures of cocksfoot and subterranean clover as a viable alternative if managed appropriately. 
Overall, these results add to the growing body of literature (Ates et al. 2010, this volume; Brown et al. 2006; Brown et al. 2005; Kearney et al. 2010, this volume; Knowles et al. 2003; Mills et al. 2008a; 2008b; Tonmukaykul et al. 2009) that suggests ryegrass and white clover are inappropriate for dryland pasture production in low rainfall $(<750 \mathrm{~mm} / \mathrm{yr})$ environments. The persistence of perennial ryegrass in this dryland experiment has been poor and it contributed only $19 \%$ of total DM in Year 7 (Fig. 4). The rate of decline over the 7 years has been disappointing given that the total annual rainfall $(460-785 \mathrm{~mm} / \mathrm{yr})$ has been average, or above average, in five of the seven growth seasons. After a period of relative yield stability between Years 2-5 (Mills et al. 2008a), ryegrass yield has approximately halved. The invasion of unsown annual and perennial weed species compromised the productivity and quality of these pastures. The AR1 endophyte should have protected the perennial ryegrass from Argentine stem weevil (Listronotus bonariensis) but periodic drought and an inability to access soil moisture stored at $>0.8 \mathrm{~m}$ soil depth (Tonmukaykul et al. 2009), plus the presence of other pasture pests (e.g. root aphids; Aploneura lentisci) may have contributed to its decline. Regardless of the reasons, perennial ryegrass has failed to persist and its continued use as the dominant grass sown in this and similar environments is questionable. Furthermore, the low N\% (Table 6) of the ryegrass suggests available $\mathrm{N}$ from soil mineralisation or fixation from associated white clover was inadequate to maintain maximum photosynthesis rates (Peri et al. 2002) and water use efficiency (Tonmukaykul et al. 2009). This low leaf $\mathrm{N}$ will also limit leaf expansion, reducing light interception and consequently potential yield. The addition of $\mathrm{N}$ fertilisers may overcome some of this problem (Fasi et al. 2008) but is not usually viable across dryland farms.

\section{Conclusions}

Lucerne and subterranean clover with cocksfoot have shown superior animal and dry matter production over 7 years and should be promoted to improve production within dryland farming systems.

\section{ACKNOWLEDGEMENTS}

Financial assistance was from Lincoln University and Beef + Lamb New Zealand through the FoRST Pastoral 21 programme.

\section{REFERENCES}

Ates, S.; Tongel, M.O.; Moot, D.J. 2010. Annual herbage production increased $40 \%$ when subterranean clover was over-drilled into grass-dominant dryland pastures. Proceedings of the New Zealand Grassland Association 72: 3-10.
Avery, D.; Avery, F.; Ogle, G.I.; Wills, B.J.; Moot, D.J. 2008. Adapting farm systems to a drier future. Proceedings of the New Zealand Grassland Association 70: 13-18.

Brown, H.E.; Moot, D.J.; Pollock, K.M. 2005. Herbage production, persistence, nutritive characteristics and water use of perennial forages grown over 6 years on a Wakanui silt loam. New Zealand Journal of Agricultural Research 48: 423-429.

Brown, H.E.; Moot, D.J.; Lucas, R.J.; Smith, M. 2006. Sub clover, cocksfoot and lucerne combine to improve dryland stock production. Proceedings of the New Zealand Grassland Association 68: 109-115.

Cayley, J.W.D.; Bird, P.R. 1996. Techniques for Measuring Pastures. 2nd Edition. Pastoral and Veterinary Institute, Hamilton, Vic. 51 pp.

Costello, T.; Costello, A. 2003. Subterranean clover in North Canterbury sheep pastures. Legumes for Dryland Pastures. Grassland Research and Practice Series 11: 189-192.

Fasi, V.; Mills, A.; Moot, D.J.; Scott, W.R; Pollock, K. 2008. Establishment, annual yield and nitrogen response of eight perennial grasses in a high country environment. Proceedings of the New Zealand Grassland Association 70: 123-130.

Kearney, J.K.; Moot, D.J.; Pollock, K.M. 2010. Onfarm comparison production in relation to rainfall in Central Otago. Proceedings of the New Zealand Grassland Association 72: 121-126.

Mills, A.; Smith, M.C.; Lucas, R.J.; Moot, D.J. 2008a. Dryland pasture yields and botanical composition over 5 years under sheep grazing in Canterbury. Proceedings of the New Zealand Grassland Association 70: 37-44.

Mills, A.; Smith, M.C.; Moot, D.J. 2008b. Liveweight production from dryland lucerne, cocksfoot or ryegrass based pastures. In: Global Issues, Paddock Action. Proceedings of the 14th ASA Conference, 21-25 September 2008, Adelaide, South Australia. http://www.regional.org.au/au/asa/2008/concurrent/ managing pastures $/ 5830$ millsa.htm.

Moot, D.J.; Brown, H.E.; Teixeira, E.I.; Pollock, K.M. 2003. Crop growth and development affect seasonal priorities for lucerne management. Legumes for Dryland Pastures. Grassland Research and Practice Series No. 11: 201-208.

Peri, P.L.; Moot, D.J.; McNeil, D.L., Varella, A.C.; Lucas, R.J. 2002. Modelling net photosynthetic rate of field-grown cocksfoot leaves under different nitrogen, water and temperature regimes. Grass and Forage Science 57: 61-71.

Tonmukaykul, N.; Moot, D.J.; Mills, A. 2009. Spring water use efficiency of six dryland pastures in Canterbury. Proceedings of the Agronomy Society of New Zealand 39: (In Press). 
